\title{
Tsunami hazard assessment in El Salvador, Central America, from seismic sources through flooding numerical models.
}

\author{
J. A. Álvarez-Gómez ${ }^{1,2}$, Í. Aniel-Quiroga ${ }^{2}$, O. Q. Gutiérrez-Gutiérrez ${ }^{2}$, J. Larreynaga ${ }^{3}$, M. González ${ }^{2}$, M. Castro ${ }^{3}$, \\ F. Gavidia ${ }^{3}$, I. Aguirre-Ayerbe ${ }^{2}$, P. González-Riancho ${ }^{2}$, and E. Carreño ${ }^{4}$ \\ ${ }^{1}$ Department of Geodynamics, Faculty of Geology, Complutense University of Madrid, C/ José Antonio Novais, s/n, \\ 28040 Madrid, Spain \\ ${ }^{2}$ Environmental Hydraulics Institute "IH Cantabria”, Universidad de Cantabria, C/ Isabel Torres no 15, \\ Parque Científico y Tecnológico de Cantabria, 39011 Santander, Spain \\ ${ }^{3}$ Department of Oceanography, General Directorate of Environmental Monitoring, Ministry of Environment and \\ Natural Resources, C/ Las Mercedes, San Salvador, El Salvador \\ ${ }^{4}$ Instituto Geográfico Nacional, C/ General Ibáñez Ibero, no. 3, 28003 Madrid, Spain
}

Correspondence to: J. A. Álvarez-Gómez (jaalvare@ucm.es)

Received: 3 January 2013 - Published in Nat. Hazards Earth Syst. Sci. Discuss.: 17 May 2013

Revised: 14 October 2013 - Accepted: 15 October 2013 - Published: 19 November 2013

\begin{abstract}
El Salvador is the smallest and most densely populated country in Central America; its coast has an approximate length of $320 \mathrm{~km}, 29$ municipalities and more than 700000 inhabitants. In El Salvador there were 15 recorded tsunamis between 1859 and 2012, 3 of them causing damages and resulting in hundreds of victims. Hazard assessment is commonly based on propagation numerical models for earthquake-generated tsunamis and can be approached through both probabilistic and deterministic methods. A deterministic approximation has been applied in this study as it provides essential information for coastal planning and management. The objective of the research was twofold: on the one hand the characterization of the threat over the entire coast of El Salvador, and on the other the computation of flooding maps for the three main localities of the Salvadorian coast. For the latter we developed high-resolution flooding models. For the former, due to the extension of the coastal area, we computed maximum elevation maps, and from the elevation in the near shore we computed an estimation of the run-up and the flooded area using empirical relations. We have considered local sources located in the Middle America Trench, characterized seismotectonically, and distant sources in the rest of Pacific Basin, using historical and recent earthquakes and tsunamis. We used a hybrid finite differencesfinite volumes numerical model in this work, based on the linear and non-linear shallow water equations, to simulate a total of 24 earthquake-generated tsunami scenarios. Our
\end{abstract}

results show that at the western Salvadorian coast, run-up values higher than $5 \mathrm{~m}$ are common, while in the eastern area, approximately from La Libertad to the Gulf of Fonseca, the run-up values are lower. The more exposed areas to flooding are the lowlands in the Lempa River delta and the Barra de Santiago Western Plains. The results of the empirical approximation used for the whole country are similar to the results obtained with the high-resolution numerical modelling, being a good and fast approximation to obtain preliminary tsunami hazard estimations. In Acajutla and La Libertad, both important tourism centres being actively developed, flooding depths between 2 and $4 \mathrm{~m}$ are frequent, accompanied with high and very high person instability hazard. Inside the Gulf of Fonseca the impact of the waves is almost negligible.

\section{Introduction}

Tsunamis are a relatively infrequent phenomena representing a greater threat than earthquakes, hurricanes and tornadoes, and causing the loss of more than 420000 human lives since 1850 as well as extensive damage to coastal infrastructure around the world. Advances in the understanding and forecasting of tsunami impacts allow for the development of adaptation and mitigation strategies to reduce risk at coastal areas. 
El Salvador is the smallest and most densely populated country in Central America. Its area covers $21393 \mathrm{~km}^{2}$, and its population is ca. 5580000 inhabitants (DIGESTYC, 2007). The coast of El Salvador has approximately a length of $320 \mathrm{~km}$, with 29 municipalities along its shore and inhabited by more than 700000 people. The country is located in an area with high seismic activity, where earthquakes, landslides and mudslides are considered major natural hazards.

In El Salvador there were 15 recorded tsunamis between 1859 and 2012, 3 of which causing damages. On 26 February 1902 an earthquake offshore Guatemala and El Salvador generated a tsunami which flooded the coast along Ahuachapán and La Paz, causing the deaths of 185 inhabitants. On 10 March 1957 a tsunami reached the coast of Acajutla due to the $M_{\mathrm{W}}=8.1$ Alaska earthquake. The tsunami caused damage in the port of Acajutla, which was under construction at that time, causing the loss of lives (Fernández, 2002). The most recent was on 27 August 2012: a $M_{\mathrm{W}}=7.3$ earthquake generated a small tsunami that affected the area of the peninsula of San Juan Del Gozo, in the Jiquilisco Bay, causing damage to some infrastructure and injuries to several people who were working at that moment in the turtle hatcheries located near the beach.

Hazard assessment is commonly based on propagation numerical models for earthquake-generated tsunamis. This models are developed through the characterization of the tsunamigenic seismic sources (faults) and the numerical modelling of the tsunami wave propagation and, if needed, flooding. Tsunami hazard assessment can be approached by both probabilistic (PTHA, Probabilistic Tsunami Hazard Assessment) and deterministic methods. When PTHA is performed, it is often considered as an extension of probabilistic seismic hazard assessment (PSHA) (Annaka et al., 2007; Burbidge et al., 2008; González et al., 2009; Grezio et al., 2010; Sørensen et al., 2012; Power et al., 2012), obtaining seismic return periods for potential tsunamigenic earthquakes and incorporating the aleatory uncertainties on the fault and tidal level parameters.

Deterministic analyses are based on worst-case scenarios, where the maximum potential tsunamigenic earthquakes are simulated. In addition, aggregated analysis combining the results obtained for a number of worst-case scenarios of tsunamis in an area can be done. A deterministic approximation has been applied in this study. This approximation provides essential information for coastal planning, engineering and management in terms of security concerns (Tinti and Armigliato, 2003).

We have developed simulations of historical and potential tsunamis, including distant, intermediate and near sources. Twenty-four scenarios of different seismic sources have been generated. The result is a catalogue of hazard maps including maximum wave elevation, maximum water depth, maximum current speed, minimum tsunami arrival time and maximum flooding level. For the whole coast of El Salvador we obtained the maximum water elevation, minimum arrival time and an estimation of the run-up level and distance. At three relevant locations of the coast we developed detailed flooding models: La Libertad, the Gulf of Fonseca - La Unión, and the western coastal plain - Acajutla. At these locations, in addition to the aforementioned maps, we obtained maps of human instability hazard, which can be defined as the hazard of drowning due to loss of stability due to the flooding depth and/or the current speed of the incoming tsunami. We used the product of both variables (Jonkman et al., 2008) and classify the results in levels following a green-yellow-red coloring scheme.

\section{Seismic sources}

From the point of view of tsunami hazard studies, tsunamigenic sources are usually classified according to their distance (temporal or spatial) with respect to the study area. The classification is simple, with near-field (or local) and farfield (or distant) sources, and occasionally in between. There is no consensus to define the boundary between the different types, although commonly used values range from 30 to 60 min of tsunami travel time as the temporal limit for separation between nearby and distant sources. Occasionally a simpler distance limit can be used, for example using from 1000 to $2000 \mathrm{~km}$ as the limit between near field and far field. This limit is a qualitative consideration beyond which the sources are considered as distant, and therefore the tsunami travel time from the source to the coast is enough to carry out evacuation plans.

For the Pacific coast of Central America we have chosen to classify the sources as distant and local because the way to approach their study and the impact of the tsunamis generated differ fundamentally. We have considered local sources as those located in the Middle America Trench from the Gulf of Tehuantepec to the Nicoya peninsula. These sources have been characterized by a detailed seismotectonic and geological study, taking also the 1992 Nicaragua earthquake and tsunami as a characteristic example of the type of subduction thrust fault event that can be generated in this area. Distant sources are the other sources in the Pacific Basin; to model these types of sources we used historical and recent earthquakes and tsunamis.

\subsection{Distant sources}

We use data from the literature on seismic sources of recent and historical destructive tsunamigenic events in the Pacific Basin. The source ruptures were characterized from inversions of geophysical and/or geodetical data (Barrientos and Ward, 1990; Hayes, 2009, 2010, 2011), from observations of tsunami waves (Johnson and Satake, 1999) or from both (Ichinose et al., 2007). There are two particular sources that could be considered intermediate because of their proximity to El Salvador but whose features have been defined based on 



Fig. 1. Seismic sources modelled in this work. (A) Far-field and intermediate sources. Rupture areas and focal mechanisms of the seismic events are shown. The empty rectangle shows the area of Fig. 1b. (B) Local sources shown as simple rectangular ruptures. The outer-rise ruptures are from Álvarez-Gómez et al. (2012), and the Nicaragua 1992 rupture area is taken from Piatanesi et al. (1996); see text for further details on the rest of subduction interface ruptures. CT, Chiapas Thrust; GT, Guatemala Thrust; EST, El Salvador Thrust.

historical events. These cases are the Mexico earthquake of 1787 and the Colombia earthquake of 1906 . For both cases the characterization of the sources has been made from historical observations (Stewart et al., 1981; Kanamori and McNally, 1982; Suárez and Albini, 2009). In Table 1 the rupture parameters for single rectangular sources of these intermediate events are shown.

In Fig. 1a, the far-field sources are shown. We attempted to incorporate the different types of large earthquakes that could take place in the Pacific Basin. In the area of Japan-Kamchatka we used the events of 1952 in
Kamchatka, with an estimated magnitude of 9.0, and the $M_{\mathrm{W}}=9.0$ Tohoku-Oki 2011 earthquake and tsunami. For the Kamchatka event we used the slip distribution of Johnson and Satake (1999), while for the Tohoku-Oki event we used the Hayes (2011) slip distribution. For the Alaska area event we used the $1964 M_{\mathrm{W}}=9.2$ with the rupture model of Ichinose et al. (2007). In South America we have used the events of $M_{\mathrm{W}}=9.5$ Chile 1960 (Barrientos and Ward, 1990) and $2010 M_{\mathrm{W}}=8.8$ (Hayes, 2010). To cover the possible events coming from Oceania, in front of the coast of Central America, we modelled the $M_{\mathrm{W}}=8.1$ Samoa-Tonga event of 2009 with the slip model of Hayes (2009). All these events have been modelled as complex ruptures from the finite-fault models published (Table 2).

\subsection{Local sources}

When defining local sources we cannot use only past events, due to the absence of a sufficient number of instrumental records. We need to study the seismotectonic characteristics of the area to characterize the local sources.

The main local tsunamigenic seismic sources in the area are related with the subduction of the Cocos Plate under the Caribbean Plate. We can split the potential tsunamigenic seismic sources into two groups: on the one hand reverse fault events of the subduction interface, and on the other normal-fault outer-rise events (Satake and Tanioka, 1999).

The reverse faulting earthquakes at the subduction interface are the most common events in subduction zones, providing the mechanism responsible for large earthquakes and tsunamis. In the study area these kinds of events are represented by the 1992 Nicaragua earthquake and tsunami (Piatanesi et al., 1996). Although the tectonic process is the same, the characteristics of the Central American subduction seems to promote the generation of tsunami earthquakes. The characteristics of this kind of earthquakes are the slow rupture velocity, the long duration, the shallow dipping thrust fault and the shallow focus (Pelayo and Wiens, 1992; Okal and Newman, 2001; López and Okal, 2006; Okal and Borrero, 2011). The analysis of the Nicaragua 1992 earthquake confirmed this earthquake as a slow tsunami earthquake (Ide et al., 1993; Imamura et al., 1993; Satake, 1994; Velasco et al., 1994) in a subduction interface with low rigidity (Satake et al., 1993; Piatanesi et al., 1996).

The normal-faulting outer-rise earthquakes are less frequent globally, but have also been responsible for damaging tsunamis in the past (Fujii and Satake, 2008; Gusman et al., 2009; Satake et al., 1992). These events are particularly common in low coupled subduction zones, as is the case of the Central American subduction (Pacheco et al., 1993; Guzmán-Speziale and Gómez-González, 2006; Lyon-Caen et al., 2006; Álvarez-Gómez et al., 2008), and have been recently studied in the area by Álvarez-Gómez et al. (2012). 
Table 1. Rectangular source model for the events of Mexico 1787 and Colombia 1906. See text for details on the parameters.

\begin{tabular}{|c|c|c|c|c|c|c|c|c|c|c|c|c|}
\hline Source & $\underset{\circ}{\text { Longitude }}$ & $\underset{\circ}{\text { Latitude }}$ & $\begin{array}{c}\text { Depth } \\
\text { km }\end{array}$ & $\begin{array}{c}\text { Length } \\
\text { km }\end{array}$ & $\begin{array}{c}\text { Width } \\
\text { km }\end{array}$ & $\begin{array}{c}\text { Strike } \\
\circ\end{array}$ & $\underset{\circ}{\operatorname{Dip}}$ & $\begin{array}{c}\text { Rake } \\
\circ\end{array}$ & $\begin{array}{c}\text { Slip } \\
\text { m }\end{array}$ & $\begin{array}{l}G \\
\mathrm{~Pa}\end{array}$ & $\begin{array}{l}M_{0} \\
\mathrm{Nm}\end{array}$ & $M_{\mathrm{W}}$ \\
\hline Mexico 1787 & -97.155 & 16.155 & 20 & 450 & 116 & 285 & 15 & 90 & 8 & $4.00 \times 10^{10}$ & $1.67 \times 10^{22}$ & 8.7 \\
\hline Colombia 1906 & -79.025 & 1.980 & 20 & 500 & 126 & 32 & 16 & 90 & 9 & $4.00 \times 10^{10}$ & $2.27 \times 10^{22}$ & 8.8 \\
\hline
\end{tabular}

Table 2. Finite-fault rupture models used for the distant recent events.

\begin{tabular}{lcl}
\hline Source & $\begin{array}{c}\text { Magnitude } \\
\left(M_{\mathrm{W}}\right)\end{array}$ & $\begin{array}{l}\text { Finite fault } \\
\text { rupture model }\end{array}$ \\
\hline Kamchatka 1952 & 9.0 & Johnson and Satake (1999) \\
Tohoku-Oki 2011 & 9.0 & Hayes (2011) \\
Alaska 1964 & 9.2 & Ichinose et al. (2007) \\
Chile 1960 & 9.5 & Barrientos and Ward (1990) \\
Chile 2010 & 8.8 & Hayes (2010) \\
Samoa-Tonga 2009 & 8.1 & Hayes (2009) \\
\hline
\end{tabular}

To simulate these normal outer-rise events we used tsunamigenic sources proposed by Álvarez-Gómez et al. (2012). For the subduction interface events we have defined new potential sources taking the 1992 Nicaragua event as a model. To define the tsunamigenic seismic sources, the parameters of spatial location, orientation (strike and dip) and dimensions of the fault are needed, in addition to the seismic rupture characteristics: rake and average slip. In order to define the location and maximum rupture length we analysed the morphology of the subduction trench to constrain a possible segmentation of the subduction zone.

The complete rupture of the subduction interface from Nicaragua to Chiapas seems unlikely given the low coupling of the subduction (Pacheco et al., 1993; Franco et al., 2012) and the lack of historical records of major events in the last six centuries (Fernández, 2002) for a subduction rate of about $70 \mathrm{~mm} \mathrm{yr}^{-1}$ (DeMets et al., 2010). We define as a segment rupture the 1992 Nicaragua event of magnitude $M_{\mathrm{W}}=7.7$ and we divided the rest of the subduction interface into three parts. The boundaries between segments have been established based in geomorphological features. We defined a segment for the Chiapas region (Chiapas Thrust, CT), from the subduction of the Tehuantepec ridge to the subduction of a bathymetric feature clearly visible in the bathymetry as a continuation of the Siqueiros fracture zone (Manea et al., 2005). From this point to the submarine canyon of San Jose, we define another segment (Guatemala Thrust, GT). We have taken the San José submarine canyon as a possible reflection of an irregularity in the upper plate lithosphere, also accompanied by a change in the orientation of the trench. Finally, from this limit and to the Gulf of Fonseca, which acted as a barrier for the 1992 Nicaragua event, we have defined the segment of El Salvador (El Salvador Thrust, EST).

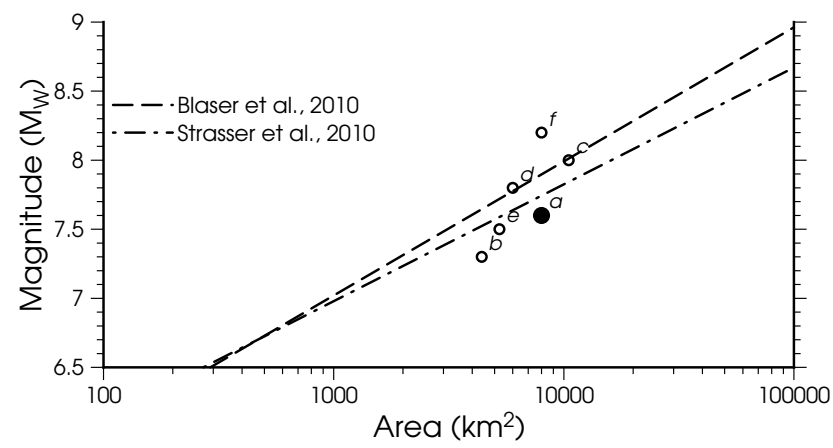

Fig. 2. Plot showing the $M_{\mathrm{W}}$-area empirical relations of Blaser et al. (2010) and Strasser et al. (2010) (dashed lines). The same relation is shown for historical tsunami earthquakes worldwide (empty circles) and the 1992 Nicaragua earthquake (filled circle). (a) 2 September 1992 Nicaragua (Ide et al., 1993; Imamura et al., 1993; Satake, 1994; Piatanesi et al., 1996), (b) 21 February 1996 Peru (Heinrich et al., 1998), (c) 15 June 1896 Sanriku (Tanioka and Satake, 1996), (d) 20 October 1963 Kuril (Beck and Ruff, 1987), (e) 10 June 1975 Kuril (Pelayo and Wiens, 1992) and (f) 1 April 1946 Aleutian Islands (Johnson and Satake, 1997).

From the subduction segmentation (Fig. 1b) we obtained the strikes of the sources and the maximum lengths for the different event ruptures. The width of the fault has been obtained from a maximum rupture depth of the subduction interface and its dip. The maximum rupture depth has been set to $20 \mathrm{~km}$, a reasonable limit given that the event of Nicaragua in 1992 had a maximum depth of rupture of $14 \mathrm{~km}$, while the dip chosen was $16^{\circ}$, the same as the Nicaragua event. These data are consistent with the recent $M_{\mathrm{W}}=7.3$ subduction event of 27 August 2012 off the coast of El Salvador. The rupture took place in the first $20 \mathrm{~km}$ of the subduction interface with a dip of $16^{\circ}$ as shown in the finite-fault model of Hayes (2012).

To obtain the maximum magnitude from the source dimensions, global empirical relationships are often used. Recently there have been studies that use data from earthquakes in subduction zones to define these relationships (Blaser et al., 2010; Strasser et al., 2010). We used the relation of Strasser et al. (2010) which relates the rupture area $(A)$ at the interface with the magnitude of the event:

$M_{\mathrm{W}}=4.441+0.846 \times \log _{10}(A)$.

If we plot this relation and the data from historical tsunami earthquakes, we can see a reasonable agreement between 
them (Fig. 2), especially for the 1992 Nicaragua event. From this moment magnitude and using the relationship of Hanks and Kanamori (1979), we obtain the seismic moment:

$\log M_{0}=1.5 M_{\mathrm{W}}+11.8$.

If we define the seismic moment as (Kanamori and Anderson, 1975)

$M_{0}=\mu \bar{D} S$,

where $\mu$ is the rigidity, $\bar{D}$ the average displacement and $S$ the rupture area, and assuming a low rigidity of $20 \mathrm{GPa}$ in the Central America subduction interface, then we can obtain the average slip for each maximum event of the subduction interface. Table 3 shows the parameters obtained for the tsunamigenic sources of the subduction interface; all have been taken as pure reverse faults.

\section{Numerical modelling}

We used the C3 numerical model (Olabarrieta et al., 2011) for this work. This model solves the linear and non-linear shallow water equations (NSWE) combining the COMCOT model (Liu et al., 1995) and Tsunami-Claw (George, 2008). The C3 model was developed in the Environmental Hydraulics Institute of the University of Cantabria, and it has been validated using theoretical events, laboratory data and real events during the project TRANSFER (Tsunami Risk and Strategies for the European Region) (see Olabarrieta et al., 2011, for more details). The COMCOT model, on which the wave propagation part of the $\mathrm{C} 3$ model relies, has been used extensively (Liu et al., 1994, 1995; Wang and Liu, 2006, 2005). Different grids can be nested to obtain an adequate resolution for the wave simulations in deep ocean and onshore conditions, optimizing the computational calculation times. The nesting of grids is done in both directions, interpolating both time and space. The model includes flooding and drying as well, which is fundamental for computing the maximum inundation (run-up).

In a Cartesian coordinate system the NSWE can be expressed as follows:

Mass conservation equation:

$\frac{\partial \zeta}{\partial t}+\frac{\partial P}{\partial x}+\frac{\partial Q}{\partial y}=0$

Momentum conservation equations:

$$
\begin{aligned}
& \frac{\partial P}{\partial t}+\frac{\partial P^{2}}{\partial x}+\frac{\partial P Q}{\partial y}+g H \frac{\partial \zeta}{\partial x}+\tau_{x} H-f Q=0, \\
& \frac{\partial P}{\partial t}+\frac{\partial P Q}{\partial x}+\frac{\partial Q^{2}}{\partial y}+g H \frac{\partial \zeta}{\partial y}+\tau_{y} H-f P=0
\end{aligned}
$$

where $\zeta$ is the free-surface elevation above mean sea level; $x$ and $y$ represent the longitude and latitude of the earth; $\tau_{x}$ and



Fig. 3. Detailed bathymetric grid levels.

$\tau_{y}$ are the bottom shear stress on the $x$ axis (pointing to the east) and the $y$ axis pointing to the north; $P$ and $Q$ stand for the volume fluxes $(P=H u$ and $Q=H v$ with $u$ and $v$ being the depth-averaged velocities in the longitude and latitude direction); $H$ is the total water depth $(H=h+\zeta)$, with $h$ being the water depth; $f$ represents the Coriolis parameter; and $g$ is the acceleration due to gravity.

Initial and boundary conditions for the simulated events can be introduced defining a fault model, in the case of a seismic source, or defining a seafloor deformation. The seafloor deformations from the local seismic tsunamigenic sources, defined as single rectangular ruptures, have been modelled with the Okada (1985) equations included in the C3 model. The seafloor deformations of the far field sources, defined as slip variable ruptures, have been computed by means of the Okada (1992) equations implemented in the program Coulomb 3.3 (Toda et al., 2011), developed on Matlab.

We used several data sources to build the bathymetric grids for the propagation and flooding numerical models: the (1) Gebco_08 (GEBCO, 2008) bathymetry database, (2) digitized bathymetric charts in near-shore areas and (3) highresolution bathymetric data from hydrographic surveys. For the topography we used a digital terrain model (DTM) with a cell size of $10 \mathrm{~m}$ provided by the Ministry of Environment and Natural Resources of El Salvador. This DTM was obtained originally from the digitalization of $1: 25000$ maps. These data have been merged and six regular grids have been elaborated, included in four nested levels (Table 4, Fig. 3).

\subsection{Numerical model validation}

Our numerical model uses the COMCOT model (Liu et al., 1995) for the wave propagation. COMCOT has been widely used, being one of the most reliable tsunami simulation codes. Roshan et al. (2013) recently studied the performance of COMCOT and JNES (Japan Nuclear Energy Safety Organization) models comparing the simulation results with the DART records for the recent 2011 Tohoku-Oki event. They 
Table 3. Rectangular source model for local thrust interface earthquakes. See text for details on the parameters.

\begin{tabular}{lcccccccccccc}
\hline Source & $\begin{array}{c}\text { Longitude } \\
\circ\end{array}$ & $\begin{array}{c}\text { Latitude } \\
\circ\end{array}$ & $\begin{array}{c}\text { Depth } \\
\mathrm{km}\end{array}$ & $\begin{array}{c}\text { Length } \\
\mathrm{km}\end{array}$ & $\begin{array}{c}\text { Width } \\
\mathrm{km}\end{array}$ & $\begin{array}{c}\text { Strike } \\
\circ\end{array}$ & $\begin{array}{c}\text { Dip } \\
\circ\end{array}$ & $\begin{array}{c}\text { Rake } \\
\circ\end{array}$ & $\begin{array}{c}\text { Slip } \\
\mathrm{m}\end{array}$ & $\begin{array}{c}G \\
\text { Pa }\end{array}$ & $\begin{array}{c}M_{0} \\
\mathrm{Nm}\end{array}$ & $\begin{array}{c}M_{\mathrm{W}} \\
\text { El Salvador Thrust (EST) }\end{array}$ \\
\hline-89.5331 & 12.5094 & 10 & 260 & 73 & 292 & 16 & 90 & 4.0 & $2.00 \times 10^{10}$ & $1.52 \times 10^{21}$ & 8.1 \\
Guatemala Thrust (GT) & -91.4881 & 13.3170 & 10 & 205 & 73 & 295 & 16 & 90 & 2.6 & $2.00 \times 10^{10}$ & $7.83 \times 10^{20}$ & 7.9 \\
Chiapas Thrust(CT) & -93.6317 & 14.4406 & 10 & 330 & 73 & 301 & 16 & 90 & 5.3 & $2.00 \times 10^{10}$ & $2.58 \times 10^{21}$ & 8.2 \\
\hline
\end{tabular}

Table 4. Details of the topo-bathymetric grids used in the propagation and flooding numerical models.

\begin{tabular}{llcc}
\hline Grid & Area & Cell size & Grid size \\
\hline Level 1 & Pacific Ocean & $4^{\prime} \simeq 7400 \mathrm{~m}$ & $2851 \times 1921$ \\
Level 2 & Central America & $30^{\prime \prime} \simeq 930 \mathrm{~m}$ & $1568 \times 1088$ \\
Level 3 & El Salvador & $6^{\prime \prime} \simeq 185 \mathrm{~m}$ & $1940 \times 545$ \\
& Acajutla & & $1146 \times 798$ \\
Level 4 & La Libertad & $1^{\prime \prime} \simeq 30 \mathrm{~m}$ & $456 \times 216$ \\
& Gulf of Fonseca & & $2016 \times 1512$ \\
\hline
\end{tabular}

conclude that both codes show adequate predictions in terms of wave heights, but with the COMCOT model being more accurate (Fig. 4) than the JNES model. Tsunami travel time estimates by COMCOT are closer to observed times than the ones by JNES (Fig. 4), and the frequency content of waves is also adequately represented. In general, the COMCOT model accurately reproduces the observed maximum wave heights, travel times and wave periods for tsunami wave propagation. The greater differences between the model and the observations can be seen in the predictions for the DART buoys nearest to the tsunami source. This is probably due to the importance of the source details in the near field. The earthquake rupture details are probably not well represented in the finite sources used in the models.

\section{Results}

The objective of the research was twofold: on the one hand the characterization of the threat over the entire coast of El Salvador, and on the other the computation of flooding maps for the three main localities of the Salvadorian coast. For the later we developed detailed flooding models. For the former, due to the extension of the coastal area, we computed maximum elevation maps and from the elevation in the near shore we computed an estimation of the run-up and the flooded area using the Synolakis (1987) relations adapted to El Salvador (a similar approximation was used for the state of California; Eisner et al., 2001; Barberopoulou et al., 2011).

As described above, 24 tsunami scenarios from different seismic sources at different locations that could impact the study area have been defined. Instead of presenting the set of maps produced for each scenario, we have elaborated aggregated maps, which means that they combine results of all the considered scenarios into one unique map. In this map each variable has a value on each point of the grid. That value usually is chosen to be the maximum of all the values obtained from the numerical simulations. This type of maps allows for graphically representing the worst condition on every point in one unique map.

\subsection{Hazard map at national scale}

The following variables are represented in the tsunami hazard map for El Salvador (Fig. 5) for the whole coast: maximum wave elevation (MWE) in the sea (metres), using the equinoctial highest tidal level as reference $(2.0 \mathrm{~m})$; run-up (m), defined as the maximum topographic elevation reached during flooding, represented with vertical bars all along the coast; minimum tsunami travel time (min) and maximum flooding area as the maximum limit of flooding by tsunami onshore.

In this case the maximum flooding has been obtained applying the empiric formulation of Synolakis (1987) to obtain the run-up from the wave elevation computed with the C3 model at the near shore with the breaking wave criteria of Gjevik and Pedersen (1981). These punctual values at the coast have been used to generate a run-up grid with a nearest-neighbour interpolating algorithm. Subtracting the topography from this grid we obtain an estimated flooded area on those cells with positive values. This approximation has been used in a similar way previously (Eisner et al., 2001; Barberopoulou et al., 2011).

As can be seen in Fig. 5 the MWE obtained near the shore ranges from $1 \mathrm{~m}$ in the area of La Unión and the Gulf of Fonseca to more than $3 \mathrm{~m}$ in the area of the Lempa River delta and Acajutla-Barra de Santiago.

The maximum run-up values are obtained in the area of Acajutla, La Libertad and two locations near the Gulf of Fonseca: Playa el Cuco and Punta Amapala. In these locations run-up values higher than $6 \mathrm{~m}$ are expected, with a maximum of $7.2 \mathrm{~m}$ at La Libertad. At the western Salvadorian coast, run-up values higher than $5 \mathrm{~m}$ are common, while in the eastern area, approximately from La Libertad to the Gulf of Fonseca, the run-up values are lower.

The more exposed areas to flooding are the lowlands in the Lempa River delta and Barra de Santiago. These are marshy areas and lagoons behind low-relief coastal sandy bars. In Fig. 5 the maximum flooded area estimation is shown. When the friction is taken into account, as in the local flooding models simulated, the run-up distance, and thus the flooded area, is lower. 

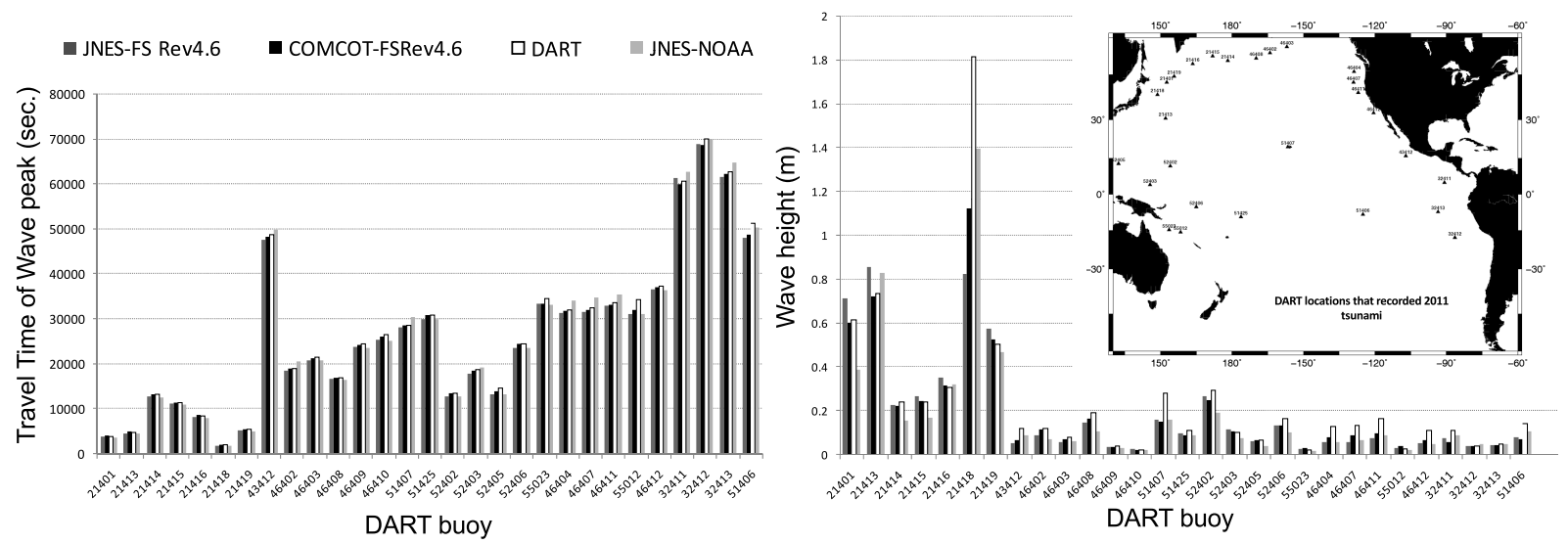

Fig. 4. Numerical model performance comparison from Roshan et al. (2013). The bars show the maximum height (left) and tsunami travel time (right) predicted by the models and compared to the DART buoys data for the Tohoku-Oki 2011 tsunami.



Fig. 5. El Salvador tsunami hazard map. Deterministic aggregated map of maximum wave elevation (MWE) from all the seismic sources modelled. White dashed lines are minimum tsunami travel times. The coloured bars show the estimated run-up computed with the Synolakis (1987) relation from the MWE. Red-filled area shows the estimated flooding area from the computed run-up elevations.

The area where the waves are expected to reach in the shortest time is that of Punta Remedios and Los Cobanos beach; where the minimum tsunami travel time is $25 \mathrm{~min}$; for the rest of the country the minimum tsunami travel time is around $30 \mathrm{~min}$, increasing towards the east with values of 45 min near the Gulf of Fonseca and more than $1 \mathrm{~h}$ inside the gulf.

\subsection{Local flooding maps}

Four types of map have been generated for each location: (1) maximum wave elevation map, (2) maximum flood depth map, (3) maximum current speed and (4) person (or human) instability hazard map. In order to calculate the worst-case scenario, as it is a deterministic study, the equinoctial highest tidal level on each area has been considered: $+2.0 \mathrm{~m}$ at $\mathrm{La}$ Libertad and Acajutla, and $+3.0 \mathrm{~m}$ at the Gulf of Fonseca. For the local maps the flooding has been computed using the C3 model. From the maximum depth and maximum current speed on each scenario we computed the flood depth-flood current speed product. This product is used to estimate the human instability hazard and is classified in levels (Jonkman et al., 2008) according to a semaphore criterion.

\subsubsection{Acajutla}

The area of Acajutla-Barra de Santiago is characterized by two distinct zones. In the western and central parts the relief 



Fig. 6. Flooding map for Acajutla. Deterministic aggregated map from all the seismic sources modelled of (a) maximum wave elevation (MWE), (b) maximum flood depth, (c) maximum current speed and (d) person instability hazard map. Dashed lines show minimum tsunami travel time.

is very low and lagoons and marshes are common, while in the eastern edge the coast is steeper. This produces greater flooding areas in the west, while towards the east the flooding area is smaller but the flood depth and person instability hazard is greater (Fig. 6).

Maximum water elevations of $4 \mathrm{~m}$ are widely produced along the coast, and maximum values of ca. $8 \mathrm{~m}$ are reached south of the port of Acajutla, where a fuel storage area is situated. In the marshy area towards the El Salvador-Guatemala boundary, MWEs of $5 \mathrm{~m}$ are reached.

The coast from the port of Acajutla towards the west can be affected by severe flooding with depths of $2 \mathrm{~m}$ and high current speeds due to its closeness to the coast. In this populated area the person instability hazard is high and the potential evacuation routes scarce.

\subsubsection{La Libertad}

In the area of La Libertad the MWE is greater than $3 \mathrm{~m}$, and in the pier area more than $4 \mathrm{~m}$ is reached (Fig. 7). Towards the west, where the coast is steeper and rocky, MWEs of 5 and $6 \mathrm{~m}$ can be generated.

Flood depths of $4 \mathrm{~m}$ are frequent, and the flooded area is considerable, especially in the east of the municipality. Here, the coastal plain between the beach and the hills, an area of tourism that is being developed, is completely flooded.

The person instability hazard is very high due essentially to the closeness to the coast. High depths and current speeds makes this zone very dangerous in the case of a tsunami. 




Fig. 7. Flooding map for La Libertad. Deterministic aggregated map from all the seismic sources modelled of (a) maximum wave elevation (MWE), (b) maximum flood depth, (c) maximum current speed and (d) person instability hazard map. Dashed lines show minimum tsunami travel time.

\subsubsection{Gulf of Fonseca - La Unión}

The Gulf of Fonseca is a great extension of shallow water and marshy coasts with small islands inside. This is Honduras' only section of Pacific coast, shared with El Salvador towards the west and with Nicaragua towards the east. Inside the gulf the impact of the waves is almost negligible, with an MWE of around $1.5 \mathrm{~m}$ in the worst cases (Fig. 8). In the area of La Unión, an important port for El Salvador, an MWE of $1 \mathrm{~m}$ is reached in the worst cases.

Due to the low impact of the tsunami waves inside the Gulf of Fonseca, the person instability hazard in the area is generally low. The tsunami travel time is greater than $1 \mathrm{~h}$, being 90 min for the port of La Unión.

\section{Discussion}

We used an empirical approximation for the whole country in order to obtain an estimated flooding area. The Synolakis (1987) relations with the breaking wave criteria of Gjevik and Pedersen (1981) have been used. We can compare the flooding areas obtained through the empirical formulation, with the flooding areas obtained with the numerical models in the local grids (Acajutla, La Libertad and the Gulf of Fonseca). The results of the empirical approximation are similar to the results obtained with the numerical modelling. The flooding areas obtained with the Synolakis (1987) empirical relations are a bit more conservative (more flooding) than the flooding areas obtained with the flooding models. This is basically due to the fact that the numerical model includes turbulence dissipation (tsunami wave breaking) and bottom friction, and thus being more realistic. In any case the empirical results seem to be good enough to obtain a preliminary, or a countrywide, tsunami hazard estimation.

The maximum estimated run-up (countrywide) in La Libertad (7.2 m, Fig. 5) is a bit higher than that obtained with the flooding models ( $\sim 6 \mathrm{~m}$, Fig. 7$)$. In the area of Acajutla and the western plains, the estimated run-up is $\sim 5 \mathrm{~m}$, which correlates well with the obtained flooding with the numerical models (Fig. 6). In the Gulf of Fonseca the run-up values are lower than $2 \mathrm{~m}$ (Fig. 5), which is coherent with the results obtained in the numerical models (Fig. 8). It could be convenient to develop new numerical simulations for the Lempa River delta, which is the area of the country with most extensive flooding, in order to constrain the validity of our estimations.

In the area of Acajutla there are some aspects related to the exposure to tsunamis that should be taken into account in future urban planning and in the adoption of tsunami hazard mitigation measures. An important impact can be expected in the area south of the Acajutla dock; here MWE greater than $6 \mathrm{~m}$ are possible. This area is where fuel is mainly stored 

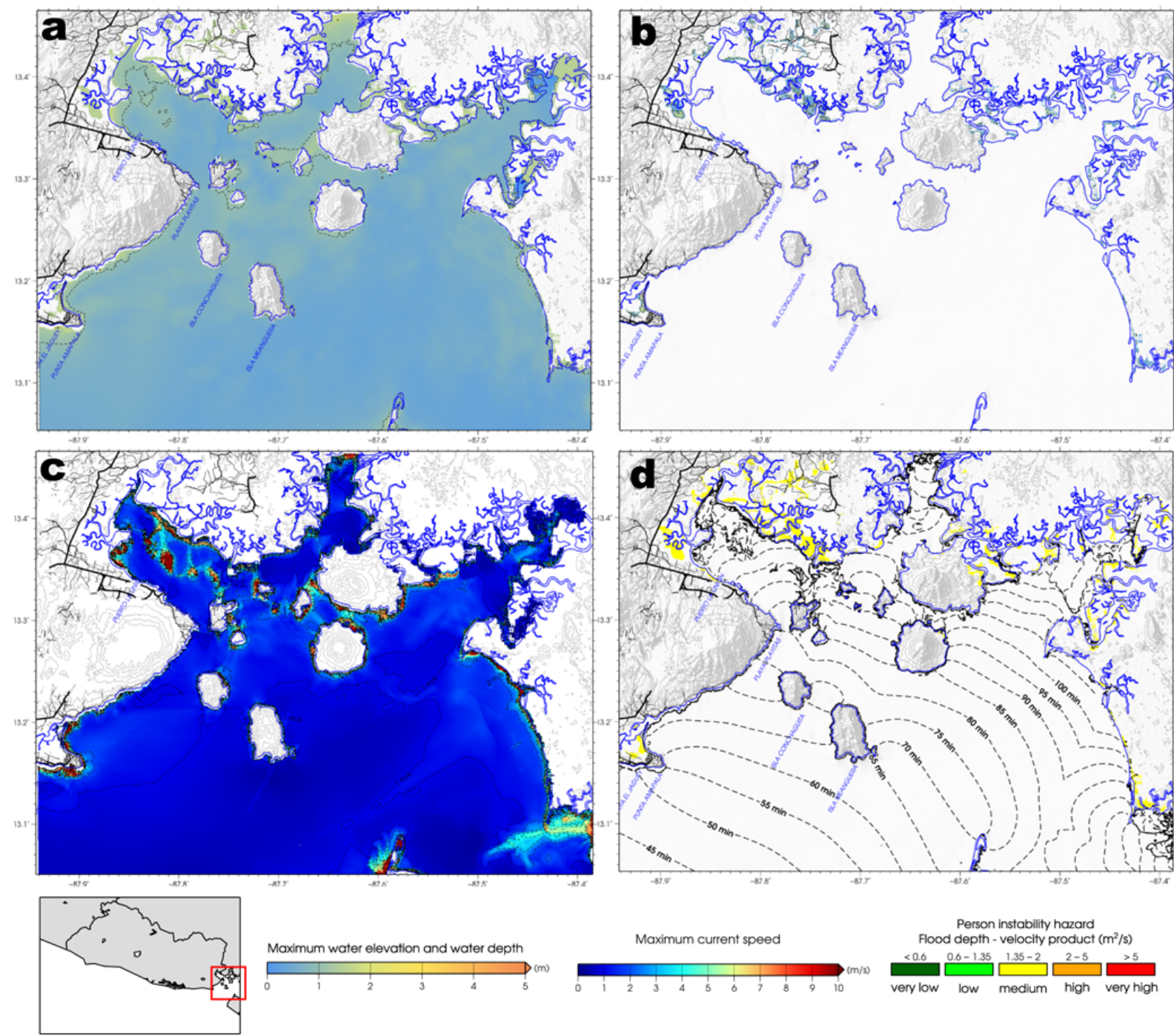

Maximum current speed

Person instability hazard

Flood depth - velocity product $\left(\mathrm{m}^{2} / \mathrm{s}\right)$

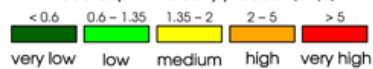

Fig. 8. Flooding map for Gulf of Fonseca - La Unión. Deterministic aggregated map from all the seismic sources modelled of (a) maximum Wave elevation (MWE), (b) maximum flood depth, (c) maximum current speed and (d) person instability hazard map. Dashed lines show minimum tsunami travel time.

and special care should be taken. To the west of Acajutla there is an important extension of tourism resorts and holiday residences, in addition to a protected environment area. This zone is widely flooded in our models and there possibilities of evacuation routes are scarce. This area was already affected by a destructive tsunami in 1902, possibly due to a local source (Lardé y Larín, 2000; Fernández, 2002; ÁlvarezGómez et al., 2012).

La Libertad is an important tourism centre. Due to its closeness to San Salvador, the capital city of the country, La Libertad is a very busy location on weekends and holidays. Its configuration on a strip parallel to the coast and the closeness to the beach of some resorts and houses makes this area very vulnerable. Moreover, the computed values of person instability hazard are very high, stressing the necessity of good evacuation plan and mitigation measures.
The flooding maps of this study are a key tool for the authorities in order to define exposed areas on each zone. The planning for mitigation measures and decision making at a local level must be done using these deterministic highresolution maps. These maps have been introduced to the Ministry of Environment of El Salvador, as well as to Civil Protection Council of the Republic of El Salvador and to the local authorities at Acajutla, La Libertad and La Unión.

\section{Conclusions}

The tsunami hazard for El Salvador has been evaluated through the use of deterministic worst-case scenarios from 24 sources. 
A countrywide hazard map for El Salvador has been developed. This map is an aggregated map from the maximum values (minimum values in the case of tsunami travel time) of the worst-case scenarios, showing MWE; minimum tsunami travel times; and estimated maximum run-up and estimated flooding areas, with both estimations based on the Synolakis (1987) relations.

Aggregated maps of MWE, minimum tsunami travel time, flooding depth and human instability hazard have been produced for the three main localities of the Salvadorian coast through high-resolution tsunami flooding numerical models. These aggregated maps are useful tools for urban development and mitigation measures planning.

At the western Salvadorian coast, run-ups higher than $5 \mathrm{~m}$ are common, while in the eastern area, approximately from La Libertad to the Gulf of Fonseca, the run-up values are lower. The maximum run-up values are above $6 \mathrm{~m}$ in Acajutla, La Libertad and near the Gulf of Fonseca. The more exposed areas to flooding are the lowlands in the Lempa River delta and the Barra de Santiago western plains (Fig. 5).

The coast from the port of Acajutla towards the west can be affected by severe flooding with depths of $2 \mathrm{~m}$ and high current speeds due to its closeness to the coast (Fig. 6). In this populated area the person instability hazard is high and the potential evacuation routes scarce.

In La Libertad flood depths of $4 \mathrm{~m}$ are frequent, and the flooded area is considerable, especially in the east of the municipality (Fig. 7). Here, the coastal plain between the beach and the hills, an area of tourism that is being developed, could be completely flooded.

Inside the Gulf of Fonseca the impact of the waves is almost negligible, with an MWE of around $1.5 \mathrm{~m}$ in the worst cases (Fig. 8). In the area of La Unión, an important port for El Salvador, MWE of $1 \mathrm{~m}$ are reached in the worst cases.

The results of the empirical approximation (countrywide) are similar to the results obtained with the numerical modelling. The flooding areas obtained with the Synolakis (1987) empirical relations are a bit more conservative (more flooding) than the flooding areas obtained with the flooding models. The empirical results seems to be good enough to obtain a preliminary tsunami hazard estimation.

It could be convenient to develop new numerical models for the Lempa River delta, which is the area of the country with more extensive flooding, in order to test the validity of our estimations.

In the areas of Acajutla and La Libertad there are some aspects related to the exposure to tsunamis that should be taken into account in future urban planning and in the adoption of tsunami hazard mitigation measures. Both are tourism centres being actively developed with areas that can be impacted by major tsunami flooding. In the case of Acajutla, evacuation routes could be difficult to implement due to the physiographic features of the western plains, with barriers, lagoons and marshes.
Acknowledgements. This work is part of the project "Tsunami Risk Assessment in El Salvador", financed by AECID (Spanish Agency for International Cooperation and Development) during the period 2009-2012. We would like to acknowledge the four anonymous reviewers for their comments and suggestions. The figures have been done mainly with GMT (Wessel and Smith, 1998).

Edited by: H. M. Fritz

Reviewed by: four anonymous referees

\section{References}

Álvarez-Gómez, J. A., Meijer, P. T., Martínez-Díaz, J. J., and Capote, R.: Constraints from finite element modeling on the active tectonics of northern Central America and the Middle America Trench, Tectonics, 27, 10.1029/2007TC002162, doi:10.1029/2007TC002162, 2008.

Álvarez-Gómez, J. A., Gutiérrez Gutiérrez, O. Q., AnielQuiroga, Í., and González, M.: Tsunamigenic potential of outer-rise normal faults at the Middle America trench in Central America, Tectonophysics, 574-575, 133-143, doi:10.1016/j.tecto.2012.08.014, 2012.

Annaka, T., Satake, K., Sakakiyama, T., Yanagisawa, K., and Shuto, N.: Logic-tree Approach for Probabilistic Tsunami Hazard Analysis and its Applications to the Japanese Coasts, Pure Appl. Geophys., 164, 577-592, doi:10.1007/s00024-006-0174-3, 2007.

Barberopoulou, A., Borrero, J. C., Uslu, B., Legg, M. R., and Synolakis, C. E.: A Second Generation of Tsunami Inundation Maps for the State of California, Pure Appl. Geophys., 168, 21332146, 2011.

Barrientos, S. E. and Ward, S. N.: The 1960 Chile earthquake: inversion for slip distribution from surface deformation, Geophys. J. Int., 103, 589-598, 1990.

Beck, S. L. and Ruff, L. J.: Rupture Process of the Great 1963 Kurile Islands Earthquake Sequence: Asperity Interaction and Multiple Event Rupture, J. Geophys. Res., 92, 14123-14138, doi:10.1029/JB092iB13p14123, 1987.

Blaser, L., Krüger, F., Ohrnberger, M., and Scherbaum, F.: Scaling Relations of Earthquake Source Parameter Estimates with Special Focus on Subduction Environment, Bull. Seismol. Soc. Am., 100, 2914-2926, doi:10.1785/0120100111, 2010.

Burbidge, D., Cummins, P. R., Mleczko, R., and Thio, H. K.: A Probabilistic Tsunami Hazard Assessment for Western Australia, Pure Appl. Geophys., 165, 2059-2088, 2008.

DeMets, C., Gordon, R. G., and Argus, D. F.: Geologically current plate motions, Geophys. J. Int., 181, 1-80, doi:10.1111/j.1365246X.2009.04491.x, 2010.

DIGESTYC: VI censo de población y V de vivienda, Tech. rep., Dirección General de Estadística y Censos, Ministry of Economy of El Salvador, 2007.

Eisner, R. K., Borrero, J. C., and Synolakis, C. E.: Inundation maps for the State of California, In ITS 2001 Proceedings, NTHMP Review Session, 67-81, Seattle, 2001.

Fernández, M.: Daños, efectos y amenaza de tsunamis en América Central, Revista Geológica de América Central, 26, 71-83, 2002.

Franco, A., Lasserre, C., Lyon-Caen, H., Kostoglodov, V., Molina, E., Guzman-Speziale, M., Monterosso, D., Robles, V., Figueroa, C., Amaya, W., Barrier, E., Chiquin, L., Moran, S., Flores, O., Romero, J., Santiago, J. A., Manea, M., and Manea, V. C.: Fault 
kinematics in northern Central America and coupling along the subduction interface of the Cocos Plate, from GPS data in Chiapas (Mexico), Guatemala and El Salvador, Geophys. J. Int., 189, 1223-1236, doi:10.1111/j.1365-246X.2012.05390.x, 2012.

Fujii, Y. and Satake, K.: Tsunami Sources of the November 2006 and January 2007 Great Kuril Earthquakes, Bull. Seismol. Soc. Am., 98, 1559-1571, doi:10.1785/0120070221, 2008.

GEBCO: The GEBCO_08 Grid, version 20081212; available at: http://www.gebco.net (last access: 25 October 2010), 2008.

George, D. L.: Augmented Riemann solvers for the shallow water equations over variable topography with steady states and inundation, J. Comput. Phys., 227, 3089-3113, doi:10.1016/j.jcp.2007.10.027, 2008.

Gjevik, B. and Pedersen, G.: Run-up of long waves on an inclined plane, vol. 2 of Preprint series, Dept of Maths, University of Oslo, 1981.

González, F. I., Geist, E. L., Jaffe, B., Kânoglu, U., Mofjeld, H., Synolakis, C. E., Titov, V. V., Arcas, D., Bellomo, D., Carlton, D., Horning, T., Johnson, J., Newman, J., Parsons, T., Peters, R., Peterson, C., Priest, G., Venturato, A., Weber, J., Wong, F., and Yalciner, A.: Probabilistic tsunami hazard assessment at Seaside, Oregon, for near- and far-field seismic sources, J. Geophys. Res., 114, C11023, doi:10.1029/2008JC005132, 2009.

Grezio, A., Marzocchi, W., Sandri, L., and Gasparini, P.: A Bayesian procedure for Probabilistic Tsunami Hazard Assessment, Nat. Hazards, 53, 159-174, doi:10.1007/s11069-0099418-8, 2010.

Gusman, A. R., Tanioka, Y., Matsumoto, H., and Iwasaki, S.-I.: Analysis of the Tsunami Generated by the Great 1977 Sumba Earthquake that Occurred in Indonesia, Bull. Seismol. Soc. Am., 99, 2169-2179, doi:10.1785/0120080324, 2009.

Guzmán-Speziale, M. and Gómez-González, J. M.: Seismic Strain rate along the Middle America Trench reveals significant differences between Cocos-North America and Cocos-Caribbean convergence, Geophys. J. Int., 166, 179-185, 2006.

Hanks, T. C. and Kanamori, H.: A Moment Magnitude Scale, J. Geophys. Res., 84, 2348-2350, doi:10.1029/JB084iB05p02348, 1979.

Hayes, G.: 2009 Mw 8.0 Samoa earthquake finite fault model, available at: http://earthquake.usgs.gov/earthquakes/eqinthenews/ 2009/us2009mdbi/finite_fault.php (last access: 1 July 2010), 2009.

Hayes, G.: 2010 Mw 8.8 Maule, Chile earthquake finite fault model, available at: http://earthquake.usgs.gov/earthquakes/ eqinthenews/2010/us2010tfan/finite_fault.php (last access: 21 June 2010), 2010.

Hayes, G.: 2011 Mw 9.0 Offshore Honshu, Japan, earthquake finite fault model, available at: http://earthquake.usgs.gov/ earthquakes/eqinthenews/2011/usc0001xgp/finite_fault.php (last access: 12 June 2011), 2011.

Hayes, G.: 2012 Mw 7.3 Offshore El Salvador earthquake finite fault model, available at: http://earthquake.usgs.gov/ earthquakes/eqinthenews/2012/usc000c7yw/finite_fault.php (last access: 3 January 2013), 2012.

Heinrich, P., Schindele, F., Guibourg, S., and Ihmlé, P. F.: Modeling of the February 1996 Peruvian Tsunami, Geophys. Res. Lett., 25, 2687-2690, doi:10.1029/98GL01780, 1998.

Ichinose, G., Somerville, P., Thio, H. K., Graves, R., and O'Connell, D.: Rupture process of the 1964 Prince William Sound,
Alaska, earthquake from the combined inversion of seismic, tsunami, and geodetic data, J. Geophys. Res., 112, B07306, doi:10.1029/2006JB004728, 2007.

Ide, S., Imamura, F., Yoshida, Y., and Abe, K.: Source characteristics of the Nicaraguan tsunami earthquake of September 2, 1992, Geophys. Res. Lett., 20, 863-866, 1993.

Imamura, F., Shuto, N., Ide, S., Yoshida, Y., and Abe, K.: Estimate of the tsunami source of the 1992 Nicaraguan earthquake from tsunami data, Geophys. Res. Lett., 20, 1515-1518, 1993.

Johnson, J. M. and Satake, K.: Estimation of seismic moment and slip distribution of the April 1, 1946, Aleutian tsunami earthquake, J. Geophys. Res., 102, 11765-11774, doi:10.1029/97JB00274, 1997.

Johnson, J. and Satake, K.: Asperity Distribution of the 1952 Great Kamchatka Earthquake and its Relation to Future Earthquake Potential in Kamchatka, in: Seismogenic and Tsunamigenic Processes in Shallow Subduction Zones, edited by: Sauber, J. and Dmowska, R., Pageoph Topical Volumes, 541-553, Birkhäuser Basel, doi:10.1007/978-3-0348-8679-6_8, 1999.

Jonkman, S., Vrijling, J., and Vrouwenvelder, A.: Methods for the estimation of loss of life due to floods: a literature review and a proposal for a new method, Nat. Hazards, 46, 353-389, doi:10.1007/s11069-008-9227-5, 2008.

Kanamori, H. and Anderson, D. L.: Theoretical basis of some empirical relations in seismology, Bull.Seismol. Soc. Am., 65, 1073-1095, 1975.

Kanamori, H. and McNally, K. C.: Variable rupture mode of the subduction zone along the Ecuador-Colombia coast, Bull. Seismol. Soc. Am., 72, 1241-1253, 1982.

Lardé y Larín, J.: El Salvador: Inundaciones e incendios, Erupciones y terremotos, Editorial DPI, San Salvador, El Salvador, 2nd Edn., 2000.

Liu, P. L. F., Cho, S., Yoon, S. B., and Seo, S. N.: Numerical simulations of the 1960 Chilean tsunami propagation and inundation at Hilo, Hawaii, Recent Development in Tsunami Research, in: Tsunami: progress in prediction, disaster prevention and warning, edited by: Tsuchiya, Y. and Shutō, N., Advances in Natural and Technological Hazards Research, 99-115, Springer, 1994.

Liu, P. L.-F., Cho, Y.-S., Briggs, M. J., Kanoglu, U., and Synolakis, C. E.: Runup of solitary waves on a circular island, J. Fluid Mechanics, 302, 259-285, 1995.

López, A. M. and Okal, E. A.: A seismological reassessment of the source of the 1946 Aleutian "tsunami" earthquake, Geophys. J. Int., 165, 835-849, 2006.

Lyon-Caen, H., Barrier, E., Lasserre, C., Franco, A., Arzu, I., Chiquin, L., Chiquin, M., Duquesnoy, T., Flores, O., Galicia, O., Luna, J., Molina, E., Porras, O., Requena, J., Robles, V., Romero, J., and Wolf, R.: Kinematics of the North American-CaribbeanCocos plates in Central America from new GPS measurements across the Polochic-Motagua fault system, Geophys. Res. Lett., 33, L19309, doi:10.1029/2006GL027694, 2006.

Manea, M., Manea, V. C., Ferrari, L., Kostoglodov, V., and Bandy, W. L.: Tectonic evolution of the Tehuantepec Ridge, Earth Planet. Sci. Lett., 238, 64-77, 2005.

Okada, Y.: Surface deformation due to shear and tensile faults in a half-space, Bull. Seismol. Soc. Am., 75, 1135-1154, 1985.

Okada, Y.: Internal deformation due to shear and tensile faults in a half-space, Bull. Seismol. Soc. Am., 82, 1018-1040, 1992. 
Okal, E. A. and Borrero, J. C.: The "tsunami earthquake" of 1932 June 22 in Manzanillo, Mexico: seismological study and tsunami simulations, Geophys. J. Int., 187(3), 1443-1459, 2011.

Okal, E. A. and Newman, A. V.: Tsunami earthquakes: the quest for a regional signal, Phys. Earth Planet. Int., 124, 45-70, 2001

Olabarrieta, M., Medina, R., Gonzalez, M., and Otero, L.: C3: A finite volume-finite difference hybrid model for tsunami propagation and runup, Comput. Geosci., 37, 1003-1014, 2011.

Pacheco, J. F., Sykes, L. R., and Scholz, C. H.: Nature of seismic coupling along simple plate boundaries of the subduction type, J. Geophys. Res., 98, 14133-14159, 1993.

Pelayo, A. M. and Wiens, D. A.: Tsunami Earthquakes: Slow Thrust-Faulting Events in the Accretionary Wedge, J. Geophys. Res., 97, 15321-15337, doi:10.1029/92JB01305, 1992.

Piatanesi, A., Tinti, S., and Gavagni, I.: The slip distribution of the 1992 Nicaraguan earthquake from tsunami run-up data, Geophys. Res. Lett., 23, 37-40, 1996.

Power, W., Wang, X., Lane, E., and Gillibrand, P.: A Probabilistic Tsunami Hazard Study of the Auckland Region, Part I: Propagation Modelling and Tsunami Hazard Assessment at the Shoreline, Pure Appl. Geophys., 1621-1634, doi:10.1007/s00024-0120543-z, 2012.

Roshan, A., Basu, P., and Jangid, R.: Performance evaluation of some tsunami numerical models for far field propagation of 2011 tsunami, International Tsunami Symposium (ITS2013), 25-28 Sept, Göceck, Turkey, 2013.

Satake, K.: Mechanism of the 1992 Nicaragua tsunami earthquake, Geophys. Res. Lett., 21, 2519-2522, 1994.

Satake, K. and Tanioka, Y.: Sources of Tsunami and Tsunamigenic Earthquakes in Subduction Zones, Pure Appl. Geophys., 154, 467-483, doi:10.1007/s000240050240, 1999.

Satake, K., Yoshida, Y., and Abe, K.: Tsunami from the Mariana earthquake of April 5, 1990: Its abnormal propagation and implications for tsunami potential from outer-rise earthquakes, Geophys. Res. Lett., 19, 301-304, 1992.

Satake, K., Bourgeois, J., Abe, K., Abe, K., Tsuji, Y., Imamura, F., Lio, Y., Katao, H., Noguera, E., and Estrada, F.: Tsunami field survey of the 1992 Nicaragua earthquake, Eos Trans. AGU, 74, 145-157, doi:10.1029/93EO00271, 1993.
Sørensen, M. B., Spada, M., Babeyko, A., Wiemer, S., and Grunthal, G.: Probabilistic tsunami hazard in the Mediterranean Sea, J. Geophys. Res., 117, B01305, doi:10.1029/2010JB008169, 2012.

Stewart, G. S., Chael, E. P., and McNally, K. C.: The November 29, 1978, Oaxaca, Mexico, Earthquake: A Large Simple Event, J. Geophys. Res., 86, 5053-5060, doi:10.1029/JB086iB06p05053, 1981.

Strasser, F. O., Arango, M. C., and Bommer, J. J.: Scaling of the Source Dimensions of Interface and Intraslab Subduction-zone Earthquakes with Moment Magnitude, Seismol. Res. Lett., 81, 941-950, doi:10.1785/gssrl.81.6.941, 2010.

Suárez, G. and Albini, P.: Evidence for Great Tsunamigenic Earthquakes (M 8.6) along the Mexican Subduction Zone, Bull. Seismol. Soc. Am., 99, 892-896, doi:10.1785/0120080201, 2009.

Synolakis, C. E.: The runup of solitary waves, J. Fluid Mechanics, 185, 523-545, 1987.

Tanioka, Y. and Satake, K.: Fault parameters of the 1896 Sanriku tsunami earthquake estimated from tsunami numerical modeling, Geophys. Res. Lett., 23, 1549-1552, 1996. doi:10.1029/96GL01479.

Tinti, S. and Armigliato, A.: The use of scenarios to evaluate the tsunami impact in southern Italy, Marine Geology, 199, 221-243, 2003.

Toda, S., Stein, R., Sevilgen, V., and Lin, J.: Coulomb 3.3 graphicrich deformation and stress-change software - user guide, Tech. Rep. 1060, US Geological Survey, 2011.

Velasco, A. A., Ammon, C. J., Lay, T., and Zhang, J.: Imaging a slow bilateral rupture with broadband seismic waves; the September 2, 1992 Nicaraguan tsunami earthquake, Geophys. Res. Lett., 21, 2629-2632, 1994.

Wang, X. and Liu, P. L.-F.: A Numerical investigation of Boumerdes-Zemmouri (Algeria) Earthquake and Tsunami, Computer Model. Eng. Sci., 10, 171-184, 2005.

Wang, X. and Liu, P. L.-F.: An analysis of 2004 Sumatra earthquake fault plane mechanisms and Indian Ocean tsunami, J. Hydraulic Res., 44, 147-154, 2006.

Wessel, P. and Smith, W. H. F.: New improved version of Generic Mapping Tools released, EOS Transactions of the American Geophysical Union, 79, 579, 1998. 